\title{
構造物の耐風設計用設計風速研究の動向 Design Wind Speeds for Structures in Various Areas
}

\section{1.はじめに}

而風構造分野では，構造骨組や外装材の而風設計のた め, 再現期間 50 年 100 年の年最大風速を設計風速とし て設定する必要がある。この風速を生じさせる風は，台 風や季節風など様々な気象要因に基づく自然現象であり, 不確定性も大きい。また, 設計風速は, 建築物, 土木構 造物, 電力施設, 風力発電, 損害保険等, 多くの分野で 必要とされるが，統一されたものにはなっていない。そ れぞれの分野の構造物には，而風設計上の特徴が異なる 背景があり，どのような風速の情報が重要であるかは， 荷重評価を行う状況毎に異なる。対象とする構造物の特 徵を反映して, 設計風速に必要とされる諸量が異なるた めに，設計基準等が分野毎に別々に規定されているのが 現状なのである。

構造物の而風設計用設計風速研究会は, 平成 26 年に発 足し, 約 2 年間活動を続けてきた。研究会では, 設計風 速の役割と変遷, 設計風速評価に関する最近の話題, 台 風モデルの適用方法等の話題を通して, さらに周辺分野 の関連問題も視野に入れながら，広く設計風速を議論す る機会を設けることを本共同研究の目的とした。
構造物の耐風設計用設計風速研究会*

Research Group on Design Wind Speeds for Structures

\section{2. 研究会の活動}

研究会では，まず現状の設計風速の状況について，分 野ごとに異なる状況を把握するために，広く他分野の研 究者にも情報提供を呼びかけて意見交換を行うこととし た。この結果，損害保険関連，海岸工学関連の研究者の 協力を得ることができ，他分野での状況を把握すること ができた。講演いただいたタイトルと講演者は以下のと おりである。

- 保険業界の ERM 経営における台風モデルの位置付け と課題（岡崎 豪, Aon Benfield Japan Ltd.)

- 海岸工学分野での台風シミュレーションの利用に関 する話題提供（森 信人，京都大学防災研究所） その他, 研究会では，委員それぞれの分野での設計風 速の話題を提供し, 情報交換が行われた。

・ 風力発電分野の設計風速と台風モデル（石原）

- 送電用鉄塔の設計風速に関する現状と課題（石川）

- 建築分野での季節係数の導入経緯（中村）

- 原子力発電施設での竜巻最大風速の評価（松井）

- 免震構造物等での風速の継続時間の評価（松井）

- 関連する分野での信頼性設計法の動向（西嶋） 最終的に異なる分野の設計風速の現状と変遷について のまとめが行われた。

本特集にて，その一部をご紹介したい

* 松井 正宏 (主査, 東京工芸大学), 西嶋 一欽 (幹事, 京都大学防災研究所), 石川 智巳 (電力中央研究所), 石原 孟 (東京大学大学院), 岡崎 豪 (エーオンベンフィールドジャパン株式会社), 勝地 弘 (横浜国立大学大学院), 中村 修 (風工学研究所), 野田 稔 (徳島大学大学院) Masahiro MATSUI, Tokyo Polytechnic University, Kazuyoshi NISHIJIMA, Kyoto University, Tomomi ISHIKAWA, Central Research Institute of Electric Power Industry, Takeshi ISHIHARA, University of Tokyo, Takeshi OKAZAKI, Aon Benfield Japan Ltd., Hiroshi OKAZAKI, Yokohama National University, Osamu NAKAMURA, Wind Engineering Institute Co., Ltd., Minoru NODA, Tokushima University 